\title{
Analysis of Animal Models of Oral Ulcers Based on the Characteristics of Clinical Symptoms of Chinese and Western Medicine
}

\author{
Huan LI, Ming BAI, Yan-yan MIAO and Ming-san MIAO* \\ Henan University of Traditional Chinese Medicine, Zhengzhou, China \\ ${ }^{*}$ Corresponding author
}

Keywords: Chinese and Western medicine, Oral ulcers, Animal model.

\begin{abstract}
Objective: To analyze the methods and characteristics of animal model of oral ulcer and the characteristics of Chinese and Western medicine oral ulcer disease anastomosis. Methods: To summarize the characteristics of animal models of oral ulcers, modeling methods, analysis of oral ulcer animal model and clinical features of the anastomosis, according to oral ulcers in Western medicine diagnostic criteria and clinical features, to discuss the advantages and disadvantages of the existing oral ulcer animal model and improve the recommendations. Results: At present, there are many methods of oral ulcer modeling, which reflects the characteristics of clinical symptoms of oral ulcer, but lacks the animal model which can reflect the characteristics of traditional Chinese medicine and western medicine, and lacks the method of evaluating oral ulcer model. conclusions: The establishment of a reliable oral ulcer evaluation method, establishing a disease - associated oral ulcer model is the focus of future research.
\end{abstract}

\section{Introduction}

Oral ulcers (oral ulcer) is one of the most common oral mucosal diseases. The prevalence rate of more than $10 \%$. Mouth ulcers refers to oral mucosal epithelial cells shedding after epithelial damage, it is a common disease. Round or oval ulceration on the oral mucosa, superficial ulceration, pale yellow or white, central depression, neat edges, around to flush, is the main clinical manifestations of oral ulcers, additionally, ulcers can occur in the oral mucosa any site [1]. According to the depth of ulceration, ulceration in clinical divided into shallow and deep ulcers. Shallow ulceration attack mere to the epithelial surface, generally do not leave scars after healing. However, deep ulceration was able to damage the deep connective tissue, leaving scars after healing. Clinical oral ulcers can be divided into: recurrent oral ulcers, behcet's disease, oral mucosal injury ulcers, vesicular stomatitis, erythema multiforme, tuberculous ulcers, contact stomatitis, necrotizing gingivostomatitis and cancerous ulcer. Wherein the recurrent oral ulcers, traumatic ulcers and herpetic stomatitis most common. Cancerous ulcer is the most dangerous [2]. Currently, the methods to establish the model of oral ulcers are mainly immune induction method, chemotherapy method, burning method, mechanical method, inducing bacterial infection method, radiation method, chemical burning method [3]. Oral ulcers, although not severe, but can affect the patient's eating, talking, and easy to relapse, affecting the quality of life of patients. Because the cause of the disease is not entirely clear, clinical efficacy has yet to be improved. Clinically, to extend the cycle of ulcers, shorten the onset time, systemic medication and local symptomatic treatment to relieve pain and promote ulcer healing [4]. 


\section{Oral Ulcers Etiology and Pathogenesis}

\section{Oral Ulcers Modern Medicine Etiology and Pathogenesis}

Western medicine perspective, oral ulcers may be associated with immune dysfunction, bacterial or viral infections, metabolic disorders, vitamin deficiency, endocrine abnormalities, digestive disorders and mental factors. Principle of treatment is to prevent secondary infection, relieve pain, promote healing and shorten the course of treatment, to avoid recurrence [5]. At present oral ulcer drugs commonly used in clinical treatment are:vitamin, antibacterial drugs, topical application promote epithelial healing drugs, designed to alleviate pain, promote ulcer healing. Severe cases, the use of immunosuppressive agents, however, such drugs toxic side effects.

\section{Etiology and pathogenesis and treatment of Traditional Chinese Medicine (TCM) of oral ulcers}

Oral ulcers belonging "aphtha", "mouth ulcers" category in the field of TCM. The Plain Question. Gas Alternating Large Theory He said: "The golden years less, flames upward ...... people sick mouth sores, and even the heartache,shows that fire-evil is a causative factor of aphthous. To Treat Patients On The Tongue Door written by Chao Yuan Fang Sui Dynasty, Say: "Hand lack of Yin, through the heart, the heart air through the tongue; full lunar, after the spleen, spleen gas reaches the mouth, internal organs excessive heat, heat to the Heart and gas rushed mouth and his tongue, it makes mouth sores. "This indicates that there is hot and humid in the heart has a close relationship with oral ulcers, heat toxin upside into the mouth, which led to occurrence of oral ulcers. While Chinese medicine believes that oral dirty and susceptible to foul toxicity causes mouth ulcers, tongue is the the seedlings of heart, Splenic pulse in the tongue, heat toxin filled, intrinsic Heart and after Heat toxin susceptible to heart along Meridians, the Yin and Blood consumption, Qi stagnation, the skin lost in Ruyang, Firelight on inflammation, splenic fever upstream steam fumigation tongue, oral ulcers generated.

\section{Clinical Characteristics of Oral Ulcers}

\section{Oral Ulcers Diagnostic Criteria and Clinical Manifestations of Western Medicine is Shown In Table 1 [2]}

Table 1. oral ulcers diagnostic criteria and clinical manifestations of Western medicine

\begin{tabular}{|c|c|c|}
\hline & Recurrent oral ulcer & Damage of the oral mucosa ulcer \\
\hline $\begin{array}{l}\text { Diagnostic } \\
\text { criteria }\end{array}$ & $\begin{array}{l}\text { (1) female } \\
\text { susceptible; (2) occurs } \\
\text { throughout the oral } \\
\text { mucosa; (3) shallow } \\
\text { ulcers, round or oval, } \\
\text { generally } 7 \text { - } 10 \text { days } \\
\text { of healing, no scar } \\
\text { after healing, but can } \\
\text { relapse. }\end{array}$ & $\begin{array}{l}\text { (1) more common in adults, especially the elderly susceptible; } \\
\text { (2) lesions are located in the stimulus contact or adjacent parts; } \\
\text { (3) early stimulation by mucosal redness, heavy stimulation caused by } \\
\text { ulcer formation; } \\
\text { (4) ulcer shape and the shape of the stimulus consistent; } \\
\text { (5) long-term stimulation, the formation of deep ulcers,central } \\
\text { depression, the surface has yellow and white pseudomembrane; } \\
\text { (6) ulcer pain is not obvious; } \\
\text { (7) to remove the local mechanical stimulation, ulcers soon disappeared. }\end{array}$ \\
\hline $\begin{array}{l}\text { Biochemical } \\
\text { index }\end{array}$ & \multicolumn{2}{|c|}{$\begin{array}{l}\text { (1)TNF- } \alpha \text { levels increased in the serum; (2)CD4 + cells was significantly reduced in the } \\
\text { peripheral blood; (3) superoxide dismutase SOD activity decreased in the serum; (4) } \\
\text { malondialdehyde (MDA) content increased; (5)IL-8 was significantly increased. }\end{array}$} \\
\hline
\end{tabular}

Note: Recurrent oral ulcers in line with a item of $33.33 \%$, (the diagnostic criteria set at $100 \%$, three criteria, each about $33.33 \%$ ); oral mucosal injury ulcer in line with a $14.285 \%$, (the diagnostic criteria for the $100 \%$, seven criteria, each about $14.285 \%$ ); biochemical indicators do not participate in the evaluation of the degree of compliance, as a reference 


\section{Diagnostic Criteria and Clinical Manifestations of Oral Ulcers of TCM}

\section{Diagnostic criteria [6]}

(1) the main symptoms: oral ulcers, pain, irritation pain.

(2) secondary symptoms: upset irritable, hot mouth, dry mouth, dark urine, dry stool.

(3) examination: ulcer site congestion and edema, pseudomembranous bleeding ulcer surface, neat edges, round or oval, surrounded by flush.

\section{Clinical manifestations}

TCM believes that this disease in the oral topical but is closely related to body organs dysfunction, ancient physicians believe that brimming heat of the heart and spleen, fire excess from Yin deficiency, deficiency of qi and blood deficiency of both lung and stomach yin, flaring up of deficient fire, deficiency of spleen and stomach, virtual fire pan.Chinese medicine-discrimination analysis of oral ulcer is shown in table 2.

Table 2. Chinese medicine-discrimination analysis of oral ulcer[7]

\begin{tabular}{|l|l|l|l|}
\hline Syndrome & Differentiation & Classification Symptoms & Tongue vein \\
\hline $\begin{array}{l}\text { Real } \\
\text { disease }\end{array}$ & $\begin{array}{l}\text { Brimming heat of } \\
\text { the heart and } \\
\text { spleen }\end{array}$ & $\begin{array}{l}\text { Oral pain, thirst, bad breath, constipation } \\
\text { urinate red, aphthous was yellow, } \\
\text { surrounding mucosa red, slightly swollen } \\
\text { and protruding, central depression. }\end{array}$ & $\begin{array}{l}\text { Tongue red, tip } \\
\text { of the tongue } \\
\text { burrs, yellow } \\
\text { tongue coating, } \\
\text { pulse counting. }\end{array}$ \\
\hline $\begin{array}{l}\text { Deficienc } \\
\text {-syndrome }\end{array}$ & $\begin{array}{l}\text { Fire excess from } \\
\text { Yin deficiency }\end{array}$ & $\begin{array}{l}\text { Oral pain, dry mouth and throat, } \\
\text { dysphoria hot, palpitations, night sweats. } \\
\text { microredness and swelling around the } \\
\text { aphthous. }\end{array}$ & $\begin{array}{l}\text { Red tongue, } \\
\text { tongue coating } \\
\text { thin, pulse } \\
\text { counting. }\end{array}$ \\
\cline { 2 - 5 } & $\begin{array}{l}\text { Deficiency of qi } \\
\text { and blood }\end{array}$ & $\begin{array}{l}\text { Chills, pale complexion, mental fatigue, } \\
\text { fatigue and shortness of breath, loose } \\
\text { stools. aphthous gray surface, mucosa } \\
\text { around the color pink. }\end{array}$ & $\begin{array}{l}\text { Pale tongue, } \\
\text { thin white } \\
\text { tongue coating, } \\
\text { weak pulse. }\end{array}$ \\
\hline $\begin{array}{l}\text { intermingl } \\
\text { ed } \\
\text { deficiency } \\
\text { and excess }\end{array}$ & $\begin{array}{l}\text { Qi and blood } \\
\text { deficiency of both } \\
\text { lung and stomach } \\
\text { yin, flaring up of } \\
\text { deficient fire }\end{array}$ & $\begin{array}{l}\text { Tongue edge ulcers on both sides, } \\
\text { particularly the right side, large rupture } \\
\text { surface, the center of projection, white } \\
\text { surface mucosal erosion, swelling and } \\
\text { stomain, inconvenience language, drooling. } \\
\text { fire pan }\end{array}$ & $\begin{array}{l}\text { Red tongue, } \\
\text { Thin white } \\
\text { tongue coating } \\
\text { less fluid, }\end{array}$ \\
\cline { 2 - 5 } & $\begin{array}{l}\text { Emaciation, malnutrition, malaise and } \\
\text { fatigue, loss of appetite ,oral cheeks, } \\
\text { tongue edge ulcers shows multiple points, } \\
\text { yellowish pseudomembrane covering the } \\
\text { surface,hyperemia, consciously burning } \\
\text { pain. }\end{array}$ & $\begin{array}{l}\text { Tongue coating } \\
\text { thin, } \\
\text { pink tongue, } \\
\text { less moss, } \\
\text { pulse counting. }\end{array}$ \\
\hline
\end{tabular}




\section{Animal Model of Oral Ulcers Research Status (table 3)}

Table 3. Description of oral ulcers model establishment and clinical degree matching

\begin{tabular}{|c|c|c|c|}
\hline Methods & Drug & Features and application & $\begin{array}{l}\text { Matching degree of clinical } \\
\text { Symptoms }\end{array}$ \\
\hline \multirow[b]{2}{*}{$\begin{array}{l}\text { Chemical } \\
\text { burning } \\
\text { method }\end{array}$} & $\begin{array}{l}\text { Phenol } \\
\text { burning } \\
\text { method } \\
{[8,9]}\end{array}$ & $\begin{array}{l}\text { Oral mucosal injury ulcer model. } \\
\text { Advantages: modeling method is } \\
\text { simple and easy, does not cause } \\
\text { other secondary reactions, } \\
\text { symptoms and clinical close. } \\
\text { Disadvantages: the faster the model, } \\
\text { not suitable for recurrent oral ulcers. }\end{array}$ & $\begin{array}{l}\text { Meet the diagnostic criteria } \\
\text { for TCM(1) (3), Meet the } \\
\text { diagnostic criteria for } \\
\text { Western medicine(2) (3) (4) } \\
\text { (6)(7), biochemical indicators } \\
\text { (1); anastomosis } \geq 71.43 \% \text {; } \\
\text { High anastomosis. }\end{array}$ \\
\hline & $\begin{array}{l}\text { Glacial } \\
\text { acetic acid } \\
\text { cauterization } \\
{[3]}\end{array}$ & $\begin{array}{l}\text { Oral mucosal injury ulcer model. } \\
\text { Advantages: easy to operate, ulcer } \\
\text { parts, size, depth easy to control, } \\
\text { repeatability, high success rate. } \\
\text { Disadvantages: chemical agents } \\
\text { contact with mucosal easy to spread, } \\
\text { leading to mucosal damage to } \\
\text { expand the area, the area was not } \\
\text { easy to fix the ulcer, ulcer size } \\
\text { instability, not as a recurrent oral } \\
\text { ulcer animal experiments. }\end{array}$ & $\begin{array}{l}\text { Meet the diagnostic criteria } \\
\text { for TCM(1) (3), Meet the } \\
\text { diagnostic criteria for } \\
\text { Western medicine(2) (3) (4) } \\
\text { (6)(7), biochemical indicators } \\
\text { (1); anastomosis } \geq 71.43 \% \text {; } \\
\text { High anastomosis. }\end{array}$ \\
\hline $\begin{array}{l}\text { Immune } \\
\text { induction } \\
\text { method }\end{array}$ & $\begin{array}{l}\text { Injecting } \\
\text { Freund's } \\
\text { adjuvant } \\
\text { added oral } \\
\text { mucosal tissue } \\
\text { homogenates } \\
\text { [10] }\end{array}$ & $\begin{array}{l}\text { Recurrent oral ulcer model. } \\
\text { Advantages: Immunological } \\
\text { modeling, and human oral ulcers } \\
\text { occurred very similar. } \\
\text { Disadvantages: more complex, } \\
\text { time-consuming, ulcer number and } \\
\text { location is not easy to control, for } \\
\text { the low immune caused by oral } \\
\text { ulcers.[11] }\end{array}$ & $\begin{array}{l}\text { Consistent with traditional } \\
\text { Chinese medicine diagnostic } \\
\text { criteria (1) (3), Western } \\
\text { diagnostic criteria (2) (3), } \\
\text { biochemical indicators (2) } \\
\text { (3) (4) (5); anastomosis } \geq \\
66.66 \% \text {; low anastomosis, } \\
\text { less application. }\end{array}$ \\
\hline $\begin{array}{l}\text { Chemotherapy } \\
\text { combined with } \\
\text { chemotherapy } \\
\text { burn } \\
\text { Burning } \\
\text { method }\end{array}$ & $\begin{array}{l}5 \text {-FU } \\
\text { combined } \\
\mathrm{NaOH} \text { crystal } \\
\text { burning [2] }\end{array}$ & $\begin{array}{l}\text { Oral mucosal injury ulcer. } \\
\text { Advantages: easy to operate, easy to } \\
\text { repeat, pathological changes similar } \\
\text { to humans; ulcers clear boundary, } \\
\text { surrounded by congestion and } \\
\text { edema, the ulcer surface size, shape } \\
\text { and depth is relatively close. } \\
\text { Disadvantages: Not suitable for } \\
\text { animal experiments with recurrent } \\
\text { oral ulcers. }\end{array}$ & $\begin{array}{l}\text { In line with Western } \\
\text { diagnostic criteria (2) (3) (4) } \\
\text { (5) (6) (7); anastomosis } \geq \\
85.71 \% \text {. High anastomosis, } \\
\text { widely used. Can be used as } \\
\text { a study to promote oral } \\
\text { mucosal healing. }\end{array}$ \\
\hline $\begin{array}{l}\text { Mechanical } \\
\text { methods }\end{array}$ & & $\begin{array}{l}\text { Oral mucosal injury ulcer model. } \\
\text { Advantages: mechanical method of } \\
\text { manufacturing animal oral mucosal } \\
\text { traumatic ulcers, ulcer size, depth } \\
\text { easy to control, can observe the } \\
\text { healing time and size of ulcers. } \\
\text { Disadvantages: mechanical } \\
\text { stimulation modeling, the size of its } \\
\text { strength and the role of the length of } \\
\text { time is different, is bound to lead to } \\
\text { the emergence of the disease have } \\
\text { their own characteristics. } \\
\text { Uses: Applicable to a method of } \\
\text { treatment of simple trauma caused } \\
\text { by ulcer effect of the screening } \\
\text { model.[12,13] }\end{array}$ & $\begin{array}{l}\text { In line with traditional } \\
\text { Chinese medicine diagnostic } \\
\text { criteria (1) (3), Western } \\
\text { diagnostic criteria: (2) (3) (4) } \\
\text { (5) (6) (7); anastomosis } \geq \\
85.71 \% \text {. High anastomosis, } \\
\text { widely used. }\end{array}$ \\
\hline
\end{tabular}

Note: the level of anastomosis that Western diagnostic criteria and clinical relevance of the relationship.

High anastomosis:> 70\%; moderate anastomosis:> 50\%, <70\%; low anastomosis: $<50 \%$. Chinese medicine diagnostic criteria as a reference. 


\section{Discussions}

Oral ulcers Western etiology and pathogenesis is unknown,at present, it is related to many factors such as heredity, autoimmune, imbalance of copper and zinc in the human body, iron deficiency, microcirculation disturbance, local trauma and infection. The disease is mostly in the category of "sores" of traditional Chinese medicine, Local treatment combined with systemic therapy [14]. Oral ulcers are not only associated with these factors, but also with environmental factors, systemic diseases (gastric ulcer, duodenal ulcer, cirrhosis, biliary tract disease[15], etc.), psychological factors [16] (interpersonal sensitivity, depression, anxiety, etc.) related. Most of the existing models showed significant tenderness, ulcer around the mucosal congestion, ulcers were round or oval, surrounded by flush around; but the biochemical indicators failed to show it. At present, the common animal model of oral ulcer model rabbits, rats, guinea pigs, golden hamster and so on. There are many methods for the preparation of animal models of oral ulcers, such as immune induction method, chemotherapy, electrocautery method, mechanical method, bacterial infection induction method, radiation method, chemical burning method and so on. , Has not yet formed a unified standard animal model, nor oral ulcer animal model evaluation method. Oral ulcer model is mostly Western medicine pathological model, oral ulcer animal model of the study, although there are many, but not based on traditional Chinese medicine to reproduce the oral ulcer animal model. Superimposed on the basis of the existing model of oral ulcers, the establishment of disease with animal model which has the characteristics of TCM syndromes, more suitable for Chinese medicine related research.

\section{Acknowledgements}

The research work is supported by The national "eleven five" supported program (2008BAI53B09); Henan Science and Technology Innovation Team (TCJ2014-391); science and technology innovation team of Zhengzhou city (131PCXTD612). [1]J.

van der Geer, J.A.J. Hanraads, R.A. Lupton, The art of writing a scientific article, J. Sci. Commun. 163 (2000) 51-59.

\section{References:}

[1] Pei-pei Tang, Ming Bai, Ming-san Miao, Effect on guinea pig Oral ulcers model of artemsia argyi decoction for external use, J. Journal of Chinese medicine. 27(2012)1286-1289.

[2] Jin-liang Deng, Common clinical classification and diagnosis of oral ulcers, J.China's practical medicine. 5(2010) 230-231.

[3] Qi Chen, Cheng Luo, Hong Chen, Etc, Progress of animal models of oral ulcer, J. Sichuan medical.36 (2015) 234-236.

[4] Cheng Yao, Min-he Shen, Shan-mingYuan, Establishment of animal model Oral ulcers , J. Shanxi traditional Chinese medicine. 30 (2014) 46-47.

[5] Kai Xiao, Xin Yan, Ming-sanMiao, Effect on guinea pig Oral ulcers model of nitidum for external use, J.Traditional Chinese medicine new medicine With clinical pharmacology. 23(2012) 533-537. 
[6] Xiao-yu Zheng. Chinese medicine clinical research guidelines for new drugs,chinese medical science and technology press,Beijing,The first edition,2002,pp.333-337.

[7] Jian-dong Hu, Jing Sun, Yuan Xue,Etc, Study Recurrent oral ulcers TCM syndrome and clinical factors ,J.Journal of Chinese medicine.30(2012)2348-2351.

[8] Dan-dan Liu,Ming Bai , Ming-san Miao, Effect of Asarum vinegar paste for external use Oral ulcers on guinea pig model,J.Journal of Chinese medicine.27(2012) 334-337.

[9] Dan-dan Liu, Xiao-fang Guo, Ming-san Miao, Araceae vinegar paste, paste affect wine for external use oral ulcers in guinea pigs , J.Traditional Chinese medicine pharmacology And clinical.28(2012) 93-96.

[10] Fang Zhou, Dong Li, Dan-yang Wang, Etc, Analysis of changes in Recurrent oral ulcers rats immunological function and serum factors ,J.Shanxi medical journal. 43(2014) 942-944.

[11] Jin-feng Wang, Wen-hui Liu, Xue-ning Jin,Etc, Role of licorice Ze Xie Tang formula granules for recurrent oral ulcers in rats, J.Chinese journal of experimental formulas of Chinese medicine.20(2014) 143-146.

[12] Sukhitashvili N, Imnadze I, Tabaghua G, et al, Characterization of Oral ulcer and pathological scar in nude mice model , J .Georgian MedNews.20 (2012) 82-87.

[13] Tanideh N, Namazi F, Andisheh Tadbir A, et al, Comparative assessment of the therapeutic effects of the topical and systemic forms of Hype-ricumper stratum extract on induced oral mucositis in golden hamsters,J.Int J Oral Maxillofac Surg.5(2014) 1-7.

[14] Shi Pengzhan, Progress on therapy for the treatment of recurrent oral ulcers, J. Shanxi traditional Chinese medicine.32(2011) 247-249.

[15] Suwimon Jettanacheawehankit, Siriruk Sasithanasate. Acemannan Stimulates Gingival Fibroblast Proliferation; Expres-sions of Keratino-cyte Growth Factor-1,Vascular Endothelial Growth Factor, and Type I Collagen; and Wound Healing, J.Sci, Journal of Pharmacological .10(2009) 525-531.

[16] Cowan D, Oral Aloevera as treatmen for osteoarthri is: a summary, J. $\mathrm{Br}$ Communty Nurs. 15(2010 )280-282 